\title{
Estimation of the microbial biomass in tidal flat sediment by fumigation-extraction
}

\author{
R. G. Joergensen ${ }^{1} \&$ T. Mueller ${ }^{2}$ \\ ${ }^{1}$ Institut für Bodenwissenschaften; von-Siebold-Str. 4, D-37075 Göttingen, Germany \\ 2 The Royal Veterinary \& Agricultural University, Department of Agricultural Sciences, \\ Section of Soil, Water and Plant Nutrition; 40, Thorvaldsensvej; DK-1871 Frederiksberg \\ C (Copenhagen), Denmark
}

\begin{abstract}
A transect of ten profiles was laid out in $20 \mathrm{~m}$ intervals on a tidal sand flat approximately $100 \mathrm{~m}$ from the east shore of Sylt until the next tideway was reached. Sediment samples were taken from $0-2 \mathrm{~cm}$ depth (oxic layer) and 2-4 cm depth (anoxic layer). The average content of organic carbon (C) was $2.41 \mathrm{mg} \mathrm{g}^{-1}$ in the oxic layer and $1.86 \mathrm{mg} \mathrm{g}^{-1}$ in the anoxic layer. The organic $\mathrm{C}$ content correlated positively with non-biomass $\mathrm{C}, 0.5 \mathrm{M} \mathrm{K}_{2} \mathrm{SO}_{4}$ extractable $\mathrm{C}$, total nitrogen ( $\mathrm{N}$ ), cation exchange capacity (CEC), and the textural classes $<200 \mu \mathrm{m}$, and negatively correlated with the coarse sand fraction. The average total $\mathrm{C}: \mathrm{N}$ ratio was 7.0 in the oxic layer and 6.7 in the anoxic layer, indicating that the $\mathrm{C}$ input comes entirely from the microflora. $\mathrm{CHCl}_{3}$-labile $\mathrm{C}$ was measured by the fumigation-extraction method and was converted to microbial biomass $C$ (values in brackets). The average content of $\mathrm{CHCl}_{3}$-labile C was $407 \mu \mathrm{g} \mathrm{g}^{-1}\left(903 \mu \mathrm{g} \mathrm{g}^{-1}\right)$ in the oxic layer and $214 \mu \mathrm{gg} \mathrm{g}^{-1}$ $\left(476 \mu \mathrm{g} \mathrm{g}^{-1}\right)$ in the anoxic layer. $\mathrm{CHCl}_{3}$-labile $\mathrm{C}$ did not correlate with $\mathrm{CEC}$ and the textural classes $<200$ um, indicating that conditions other than the physical environment determine this fraction (C input, grazing).
\end{abstract}

\section{INTRODUCTION}

The microbial biomass is defined as the sum of organisms smaller than $5 \times 10^{3} \mathrm{um}^{3}$ (Jenkinson \& Ladd, 1981) and is recognized as the most important fraction of organic matter in different sediments (Moriarty et al., 1985; Alongi, 1988). Heterotrophic microorganisms mineralize the greatest part of all organic material that enters the sediment ecosystem, converting it to simple inorganic compounds that can be used again by autotrophic organisms. In contrast to terrestrial soils, microbial biosynthesis can account for a significant fraction of total carbon input in sediments (Asmus \& Asmus, 1985). The biomass of the sedimentary microorganisms is itself a sink for nutrients and a food source of meio- and macrofauna, which comprises a great part of the total living benthic biomass (Reise, 1985).

Microbial biomass in sediments has mainly been measured by using direct microscopic techniques such as epifluorescence microscopy. These methods have been criticized because of the problems with quantitative recoveries of attached bacteria from particles, the limitations of accurately measuring biovolumes, and the uncertainties in the factors used to convert either cell numbers or biovolumes to biomass (Jenkinson \& Ladd, 1981; Findlay et al., 1989). Estimates of the microbial biomass by measuring the biochemical components of cells (e.g. ATP, muramic acid, ergosterol, phospholipid phosphate, 
etc.) also suffer from uncertainties in conversion factors. In addition, these methods can be time-consuming and in some cases require relatively expensive instrumentation (Findlay et al., 1989). Consequently, the knowledge about the size of the microbial biomass in tidal flat sediments is much more limited than that about faunal, especially macrofaunal biomass (Reise, 1985).

Chloroform fumigation affects the cell-membranes of small organisms and makes their biomass partially extractable. This effect is used by the fumigation-extraction method to estimate microbial biomass $C$ in terrestrial soils (Vance et al., 1987). This method has proved to be robust against handling errors and to be applicable to a wide range of soils, including water logged paddy soils (Inubushi et al., 1991) and soils which are supersaturated with salt solution (Widmer et al., 1989; Mueller et al., 1992). For this reason, the fumigation-extraction method should also be usable in order to answer the following questions:

(1) What is the size of the microbial biomass in a tidal flat sediment?

(2) What are the relationships between the microbial biomass and sediment properties?

\section{MATERIALS AND METHODS}

\section{Sediment}

Sediment samples were taken on August 26th, 1991, from a tidal sand flat sediment on the east shore of Sylt in the north of the "Kampener Vogelkoje". The island of Sylt is in the northern part of the Wadden Sea. Mean annual air temperature is $8.1^{\circ} \mathrm{C}$ and mean annual water temperature about $9{ }^{\circ} \mathrm{C}$, with a summer average of $15^{\circ} \mathrm{C}$ and a winter average of $4{ }^{\circ} \mathrm{C}$ (Reise, 1985). The upper $2 \mathrm{~cm}$ are usually brownish, stained by ferric hydroxides $\left[\mathrm{Fe}(\mathrm{OH})_{3}\right]$. Below, the colour changes abruptly to black, stained by ferrous sulfide [FeS] which in turn gives way to grey at about $7 \mathrm{~cm}$ depth, stained by pyrite $\left[\mathrm{FeS}_{2}\right]$ (Anderson \& Meadows, 1978; Reise, 1985). Approximately $100 \mathrm{~m}$ from the shore, a transect of ten profiles was laid out in $20 \mathrm{~m}$ intervals until the next tideway was reached. Sediment samples were taken from 0-2 cm depth (oxic layer) and 2-4 cm depth (anoxic layer) with a small spade. The samples were stored and cooled in a closed container and transported to Göttingen the next day.

\section{Analysis}

Dry weight was determined by heating aliquots of samples in an oven at $105^{\circ} \mathrm{C}$ to constant weight (approx. $24 \mathrm{~h}$ ). Soluble salts were measured after percolation of $10 \mathrm{~g}$ sediment with $100 \mathrm{ml}$ distilled water. Salt content was calculated by adding the weight of cations $\left(\mathrm{Na}^{+}, \mathrm{K}^{+}, \mathrm{Ca}^{2+}\right.$ and $\left.\mathrm{Mg}^{2+}\right)$ and anions $\left(\mathrm{Cl}^{-}\right.$and $\left.\mathrm{HCO}_{3}^{-}\right)$which were measured in water percolate as described by Joergensen \& Meyer (1990). Cation exchange capacity (CEC) was measured in the salt-free sediment after additional percolation with $100 \mathrm{ml}$ of $0.1 \mathrm{MBaCl}_{2}$ solution containing $5 \%$ triethanolamine as a buffer according to Mehlich (Schlichting \& Blume, 1966). $\mathrm{Ba}^{2+}$ was re-exchanged with $100 \mathrm{ml}$ of a $0.1 \mathrm{M} \mathrm{CaCl}_{2-}$ solution and measured by atomic absorption spectrometry (Varian AA-775). Sand and silt fractions $\geq 20 \mu \mathrm{m}$ were measured by sieving after treatment with $\mathrm{H}_{2} \mathrm{O}_{2}$, silt and clay $<20 \mu \mathrm{m}$ by using a pipette procedure (Schlichting \& Blume, 1966). The textural classes 
are coarse sand $(2000-630 \mu \mathrm{m})$, medium sand $(630-200 \mu \mathrm{m})$, fine sand $(200-63 \mu \mathrm{m})$, silt $(63-2 \mu \mathrm{m})$ and clay $(<2 \mu \mathrm{m})$. Total $\mathrm{C}$ and $\mathrm{N}$ was measured by gas chromatography after dry combustion to $\mathrm{CO}_{2}$ and $\mathrm{N}_{2}$ (Carlo Erba ANA 1400). The data represent the arithmetic means of triplicate analysis.

The fumigation-extraction method to estimate microbial biomass was performed according to Vance et al. (1987) after visible organisms had been removed from the sediment. Moist soils (50 g dry weight) were split into two samples of $25 \mathrm{~g}$ dry weight. The non-fumigated control samples were placed in $250 \mathrm{ml}$ bottles and then immediately extracted with $100 \mathrm{ml} 0.5 \mathrm{M} \mathrm{K}_{2} \mathrm{SO}_{4}$ (ratio of extractant: soil [dry weight] was $4: 1$ ) for 45 minutes on an overhead shaker revolving at $40 \mathrm{rev} \mathrm{min}^{-1}$ and then filtered through paper filter (Whatman 42). For the fumigated treatment, 50-ml glass vials containing the fieldmoist soils were placed in a desiccator containing wet tissue paper and a vial of soda lime. A $50-\mathrm{ml}$ beaker containing $25 \mathrm{ml}$ ethanol-free $\mathrm{CHCl}_{3}$ and a few boiling chips were added and the desiccator evacuated until the $\mathrm{CHCl}_{3}$ had boiled vigorously for two minutes. The desiccator was then incubated in the dark at a constant temperature of $25^{\circ} \mathrm{C}$ for 25 hours. After fumigation, $\mathrm{CHCl}_{3}$ was removed by repeated evacuation (six times at intervals of two minutes) to make sure that no trace of chloroform remained in the samples. The samples were transferred to $250-\mathrm{ml}$ bottles and then extracted as described above. All extracts were stored at $-15{ }^{\circ} \mathrm{C}$ prior to analysis. Organic $\mathrm{C}$ was determined in the $0.5 \mathrm{M}$ $\mathrm{K}_{2} \mathrm{SO}_{4}$ extracts with a Dohrman DC 80 automatic carbon analyzer (Wu et al., 1990). Extractable organic $\mathrm{C}$ was calculated by the equation:

$$
\begin{aligned}
& C\left(\mathrm{ug} \mathrm{g}^{-1} \text { sediment }\right)=(\mathrm{V}-\mathrm{B}) \times\left(\mathrm{A}_{\mathrm{K}}: \mathrm{S}_{\mathrm{DW}}+\mathrm{S}_{\mathrm{W}}: 100\right) \\
& \mathrm{V} \quad=\mathrm{C}\left(\mu \mathrm{g} \mathrm{ml} \mathrm{m}^{-1}\right) \text { of sample } \\
& \mathrm{B}=\mathrm{C}\left(\mu \mathrm{g} \mathrm{m} \mathrm{m}^{-1}\right) \text { of blank } \\
& \mathrm{A}_{\mathrm{K}} \quad=\text { amount of } \mathrm{K}_{2} \mathrm{SO}_{4} \\
& \mathrm{~S}_{\mathrm{DW}} \quad \text { = sediment dry weight of sample } \\
& \mathrm{S}_{\mathrm{W}} \quad \text { = sediment water (\% dry weight) }
\end{aligned}
$$

Chloroform-labile $C\left(E_{C}\right)$ was calculated by the equation:

$$
\begin{array}{ll}
\mathrm{E}_{\mathrm{C}} & =\left(\mathrm{C}_{\mathrm{F}}-\mathrm{C}_{\mathrm{U}}\right) \\
\mathrm{C}_{\mathrm{F}} & =\text { organic } \mathrm{C} \text { extracted from fumigated sediment } \\
\mathrm{C}_{\mathrm{U}} & =\text { organic } \mathrm{C} \text { extracted from non-fumigated sediment }
\end{array}
$$

Microbial biomass $\mathrm{C}\left(\mathrm{B}_{\mathrm{C}}\right)$ was calculated by the equation:

$$
\mathrm{B}_{\mathrm{C}}=2.22 \mathrm{E}_{\mathrm{C}} \text { (Wu et al., 1990) }
$$

\section{RESULTS}

The average salt concentration was $7.5 \mathrm{mg} \mathrm{g}^{-1}$ in the oxic $0-2 \mathrm{~cm}$ layer and $6.7 \mathrm{mg}$ $\mathrm{g}^{-1}$ in the anoxic $2-4 \mathrm{~cm}$ layer and showed neither a significant gradient with depth nor towards the tideway (Table 1). The cation exchange capacity ranged between 9.8 and 33.4 meq $\mathrm{kg}^{-1}$ and decreased towards the tideway and with depth in the first four profiles (Table 1). This decrease paralleled the declining percentage of the fine sand fraction, ranging from 1.7 to $45.2 \%$, and that of the silt and clay fraction (Table 2). These two fractions had an extremely small percentage and never exceeded $6.2 \%$ with a minimum 
Table 1 . Salt content and cation exchange capacity (CEC).

- Mean significant difference; $P=0.05$ (Tukey)

\begin{tabular}{|ccccc|}
\hline $\begin{array}{c}\text { Distance } \\
\text { from coast } \\
(\mathrm{m})\end{array}$ & \multicolumn{2}{c}{$\begin{array}{c}\text { Salt } \\
\left(\mathrm{mg} \mathrm{g}^{-1}\right)\end{array}$} & \multicolumn{2}{c|}{$\begin{array}{c}\mathrm{CEC} \\
\left(\mathrm{meq} \mathrm{kg}^{-1}\right)\end{array}$} \\
\hline 120 & $0-2 \mathrm{~cm}$ & $2-4 \mathrm{~cm}$ & $0-2 \mathrm{~cm}$ & $2-4 \mathrm{~cm}$ \\
140 & 8.2 & 7.3 & 27.5 & 23.5 \\
160 & 7.7 & 5.8 & 33.4 & 20.8 \\
180 & 3.7 & 6.5 & 20.8 & 14.1 \\
200 & 8.1 & 8.0 & 19.3 & 14.6 \\
220 & 7.4 & 7.2 & 16.8 & 21.4 \\
240 & 7.5 & 6.3 & 13.8 & 15.1 \\
260 & 8.5 & 5.9 & 14.6 & 13.3 \\
280 & 7.2 & 6.8 & 12.3 & 10.8 \\
300 & 8.8 & 7.3 & 10.0 & 10.5 \\
Mean & 8.1 & 6.3 & 11.5 & 9.8 \\
MSD & 7.5 & 6.7 & 18.0 & 15.4 \\
& 1.1 & 1.0 & 6.2 & 4.5 \\
\hline
\end{tabular}

Table 2. Sediment texture

\begin{tabular}{|c|c|c|c|c|c|c|c|c|c|c|}
\hline \multirow{3}{*}{$\begin{array}{c}\begin{array}{c}\text { Distance } \\
\text { from } \\
\text { coast } \\
(\mathrm{m})\end{array} \\
120\end{array}$} & \multicolumn{2}{|c|}{ Coarse sand } & \multicolumn{2}{|c|}{ Medium sand } & \multicolumn{2}{|c|}{$\begin{array}{c}\text { Fine sand } \\
(\% \text { dry weight })\end{array}$} & \multicolumn{2}{|c|}{ Silt } & \multicolumn{2}{|c|}{ Clay } \\
\hline & $0-2 \mathrm{~cm}$ & $2-4 \mathrm{~cm}$ & $0-2 \mathrm{~cm}$ & $2-4 \mathrm{~cm}$ & $0-2 \mathrm{~cm}$ & $2-4 \mathrm{~cm}$ & $0-2 \mathrm{cr}$ & $2-4 \mathrm{~cm}$ & $0-2 \mathrm{cr}$ & $-4 \mathrm{~cm}$ \\
\hline & 17.5 & 20.1 & 35.9 & 33.0 & 43.0 & 38.1 & 4.3 & 4.2 & 2.2 & 1.7 \\
\hline 140 & 15.8 & 24.7 & 30.9 & 29.4 & 45.2 & 39.7 & 6.2 & 3.3 & 3.4 & 1.5 \\
\hline 160 & 23.5 & 25.0 & 43.1 & 40.7 & 30.5 & 28.6 & 2.7 & 1.6 & 2.6 & 1.7 \\
\hline 180 & 32.2 & 34.2 & 44.6 & 41.2 & 22.8 & 19.3 & 1.6 & 1.1 & 2.2 & 0.8 \\
\hline 200 & 43.8 & 42.4 & 40.8 & 41.8 & 11.2 & 14.0 & 0.6 & 2.2 & 2.4 & 0.7 \\
\hline 220 & 55.2 & 55.5 & 28.6 & 30.0 & 12.4 & 13.3 & 0.8 & 1.3 & 1.7 & 1.2 \\
\hline 240 & 53.3 & 51.8 & 34.6 & 37.0 & 8.5 & 11.9 & 0.6 & 0.8 & 0.6 & 0.9 \\
\hline 260 & 69.0 & 59.6 & 34.6 & 28.3 & 1.9 & 4.4 & 0.4 & 0.4 & 0.4 & 1.1 \\
\hline 280 & 69.4 & 57.5 & 36.3 & 28.1 & 1.7 & 4.4 & 0.2 & 0.6 & 0.5 & 1.2 \\
\hline 300 & 58.1 & 44.7 & 48.0 & 38.5 & 2.8 & 6.2 & 0.2 & 0.3 & 0.4 & 0.8 \\
\hline Mean & 43.8 & 41.6 & 34.8 & 37.7 & 18.0 & 27.1 & 1.8 & ,1.6 & 1.7 & 1.2 \\
\hline
\end{tabular}

of $0.3 \%$. The coarse sand fraction, ranging from 15.8 to $69.4 \%$, was on average the largest fraction and had an inverse relationship to CEC and the three textural classes $<200 \mu \mathrm{m}$. No gradient could be observed for the medium sand fraction which varied around $36 \%$ (Table 2).

The average content of total organic $C$ was $2.41 \mathrm{mg} \mathrm{g}^{-1}$ in the oxic $0-2 \mathrm{~cm}$ layer and $1.86 \mathrm{mg} \mathrm{g}^{-1}$ in the anoxic $2-4 \mathrm{~cm}$ layer (Table 3 ). The organic $\mathrm{C}$ content decreased towards the tideway and was thus positively correlated with CEC and the three textural classes $<200 \mu \mathrm{m}$ and negatively correlated with the coarse sand fraction (Table 4 ). The total C:N ratio varied between 6.2 and 7.7 without consistent gradient (Table 5). The 
Table 3. Soil organic $\mathrm{C}$, extractable $\mathrm{C}$ and $\mathrm{CHCl}_{3}$-labile $\mathrm{C}$.

- Mean significant difference; $\mathrm{P}=0.05$ (Tukey)

\begin{tabular}{|c|c|c|c|c|c|c|}
\hline \multirow{2}{*}{$\begin{array}{c}\text { Distance } \\
\text { from coast } \\
(\mathrm{m})\end{array}$} & \multicolumn{2}{|c|}{$\begin{array}{l}\text { Total organic C } \\
\left(\mathrm{mg} \mathrm{g}^{-1}\right)\end{array}$} & \multicolumn{2}{|c|}{$\begin{array}{c}\text { Extractable C } \\
\left(\mu \mathrm{g} \mathrm{g}^{-1}\right)\end{array}$} & \multicolumn{2}{|c|}{$\begin{array}{c}\mathrm{CHCl}_{3} \text {-labile C } \\
\left(\mu \mathrm{g} \mathrm{g}^{-1}\right)\end{array}$} \\
\hline & $0-2 \mathrm{~cm}$ & $2-4 \mathrm{~cm}$ & $0-2 \mathrm{~cm}$ & $2-4 \mathrm{~cm}$ & $0-2 \mathrm{~cm}$ & $2-4 \mathrm{~cm}$ \\
\hline 120 & 3.03 & 2.67 & 51 & 38 & 319 & 155 \\
\hline 140 & 3.94 & 2.44 & 73 & 37 & 424 & 221 \\
\hline 160 & 3.15 & 2.05 & 60 & 39 & 444 & 261 \\
\hline 180 & 2.70 & 2.31 & 55 & 33 & 612 & 456 \\
\hline 200 & 2.49 & 2.75 & 40 & 42 & 489 & 196 \\
\hline 220 & 2.08 & 1.76 & 49 & 32 & 320 & 194 \\
\hline 240 & 1.85 & 1.34 & 43 & 30 & 402 & 206 \\
\hline 260 & 1.88 & 1.27 & 34 & 17 & 470 & 211 \\
\hline 280 & 1.63 & 1.04 & 33 & 16 & 385 & 138 \\
\hline 300 & 1.36 & 0.94 & 36 & 16 & 200 & 105 \\
\hline Mean & 2.41 & 1.86 & 48 & 30 & 407 & 214 \\
\hline MSD* & 0.32 & 0.21 & 14 & 10 & 64 & 59 \\
\hline
\end{tabular}

Table 4. Spearman rank correlation coefficients. * $\mathrm{P} \leq 0.05 ;{ }^{*} \mathrm{P} \leq 0.01 ;{ }^{*}{ }^{*} \mathrm{P} \leq 0.001$

\begin{tabular}{|lcc|}
\hline & Total organic C & $\mathrm{CHCl}_{3}$-labile C \\
\hline CEC & $0.91^{\cdots} \cdots$ & 0.25 \\
Salt & 0.12 & 0.36 \\
Coarse sand & $0.78^{\cdots}$ & -0.14 \\
Medium sand & 0.02 & 0.00 \\
Fine sand & $0.79 \cdots$ & 0.11 \\
Silt & $0.82^{\cdots} \cdots$ & 0.11 \\
Clay & $0.64^{\cdots}$ & 0.29 \\
Total N & $0.95^{\cdots}$ & $0.65^{*}$ \\
C:N & 0.33 & -0.19 \\
Extractable C & $0.87^{*} \cdots$ & $0.57^{*}$ \\
Total organic C & & $0.50^{*}$ \\
\hline
\end{tabular}

content of $0.5 \mathrm{M} \mathrm{K}_{2} \mathrm{SO}_{4}$ extractable $\mathrm{C}$ was closely correlated to total organic $\mathrm{C}$, but the decrease towards the tideway was less apparent and with depth more pronounced. Consequently, the average ratio of extractable $C$ to total organic $C$ decreased from $2.0 \times$ $10^{-2}$ in the oxic $0-2 \mathrm{~cm}$ layer to $1.6 \times 10^{-2}$ in the anoxic $2-4 \mathrm{~cm}$ layer (Table 5).

The average content of $\mathrm{CHCl}_{3}$-labile $\mathrm{C}$ was $407 \mu \mathrm{g} \mathrm{g}^{-1}$ in the oxic $0-2 \mathrm{~cm}$ layer, ranging from 200 to $612 \mu \mathrm{g} \mathrm{g}^{-1}$, and $214 \mu \mathrm{g} \mathrm{g}^{-1}$ in the anoxic $2-4 \mathrm{~cm}$ layer, ranging from 105 to $456 \mu \mathrm{g} \mathrm{g}^{-1}$ (Table 3), using the factor of Wu et al. (1990) to convert the content of $\mathrm{CHCl}_{3}$-labile $\mathrm{C}$ to microbial biomass, the corresponding average content was $903 \mu \mathrm{g} \mathrm{g}^{-1}$ in the $0-2 \mathrm{~cm}$ layer and $475 \mu \mathrm{g} \mathrm{g}^{-1}$ in the $2-4 \mathrm{~cm}$ layer. With the exception of the marked decline in the last profile directly in front of the tideway, the content of $\mathrm{CHCl}_{3}$-labile $\mathrm{C}$ showed no consistent decrease towards the tideway; thus, it was not correlated with CEC and the textural classes $<200 \mu \mathrm{m}$ (Table 4). The relations to total $\mathrm{N}, 0.5 \mathrm{M} \mathrm{K}_{2} \mathrm{SO}_{4}$ 
Table 5. Ratios

\begin{tabular}{|c|c|c|c|c|c|c|}
\hline \multirow{2}{*}{$\begin{array}{l}\text { Distance } \\
\text { from coast } \\
(\mathrm{m})\end{array}$} & \multicolumn{2}{|c|}{$\begin{array}{c}\text { Total organic } \mathrm{C}: \\
\text { total } \mathrm{N}\end{array}$} & \multicolumn{2}{|c|}{$\begin{array}{c}\text { Extractable C: } \\
\text { total organic } \mathrm{C}[\%]\end{array}$} & \multicolumn{2}{|c|}{$\begin{array}{l}\mathrm{CHCl}_{3} \text {-labile } \mathrm{C}: \\
\text { total organic } \mathrm{C}[\%]\end{array}$} \\
\hline & $0-2 \mathrm{~cm}$ & $2-4 \mathrm{~cm}$ & $0-2 \mathrm{~cm}$ & $2-4 \mathrm{~cm}$ & $0-2 \mathrm{~cm}$ & $2-4 \mathrm{~cm}$ \\
\hline 120 & 7.6 & 7.7 & 1.7 & 1.4 & 11 & 6 \\
\hline 140 & 7.3 & 6.5 & 1.8 & 1.5 & 11 & 9 \\
\hline 160 & 6.7 & 6.4 & 1.9 & 1.9 & 14 & 13 \\
\hline 180 & 6.5 & 6.2 & 2.1 & 1.4 & 23 & 20 \\
\hline 200 & 6.4 & 7.4 & 1.6 & 1.5 & 20 & 7 \\
\hline 220 & 7.7 & 7.4 & 2.4 & 1.8 & 15 & 11 \\
\hline 240 & 6.7 & 6.7 & 2.3 & 2.3 & 22 & 15 \\
\hline 260 & 7.2 & 6.2 & 1.8 & 1.3 & 25 & 17 \\
\hline 280 & 6.8 & 6.9 & 2.0 & 1.6 & 24 & 13 \\
\hline 300 & 6.8 & 6.1 & 2.6 & 1.7 & 15 & 11 \\
\hline Mean & 7.0 & 6.7 & 2.0 & 1.6 & 18 & 12 \\
\hline
\end{tabular}

extractable $C$ (from non-fumigated samples) and total organic $C$ were on a lower level of significance, indicating that conditions other than the physical environment determine the content of $\mathrm{CHCl}_{3}$-labile $\mathrm{C}$ or microbial biomass, such as $\mathrm{C}$-input or grazing by animals. The ratio $\mathrm{CHCl}_{3}$-labile $\mathrm{C}$ to total organic $\mathrm{C}$ was extremely high in both layers, on average $18 \%$ in the oxic $0-2 \mathrm{~cm}$ layer and still $12 \%$ in the anoxic $2-4 \mathrm{~cm}$ layer (Table 5 ). Using the conversion factor 2.22 of $\mathrm{Wu}$ et al. (1990), the ratio microbial biomass to total organic C would be $40 \%$ or $27 \%$, respectively.

\section{DISCUSSION}

Tidal flat sediments are formed in the transitional zone of lithosphere, biosphere, hydrosphere and atmosphere, similarly to soils. Consequently, tidal flat sediments have many features of soil. The tidal sand flat sediments of Sylt originate from terrestrial mobile sand dunes, as indicated by the high abundance of coarse grains, and may be transformed by further sedimentation to a semi-terrestrial ecosystem and at least to a terrestric agricultural ecosystem. However, from an ecologist's viewpoint, tidal flat sediments remain primarily a marine habitat, because the pore space is saturated with marine interstitial water throughout the low tide periods. The tidal exchange of water masses buffers environmental extremes and prevents local deviations in water chemistry. On the other hand, tidal flats are subjected to the extremes of terrestrial climate such as heat, frost and rain.

The C-input in tidal flat sediments comes from (1) the primary production of benthic microalgae and cyanobacteria, (2) the primary production of phytoplankton in the water column above the flats, and (3) the influx of detritus with the tides. The range of this $\mathrm{C}$ input is comparable with aboveground primary production (Reise, 1985). Jenkinson et al. (1992) estimated a net primary production between 220 and $520 \mathrm{~g} \mathrm{C} \mathrm{m}^{-2} \mathrm{a}^{-1}$ for different terrestrial ecosystems (arable, grassland and forest). However, without macrophytes such as seagrass, the net primary production on a sandy flat similar to ours was only $127 \mathrm{~g} \mathrm{C}$ 
$\mathrm{m}^{-2} \mathrm{a}^{-1}$, where $22 \%$ were produced by phytoplankton and $78 \%$ by benthic microalgae (Asmus \& Asmus, 1985).

If $\mathrm{CHCl}_{3}$-labile $\mathrm{C}$ is converted to microbial biomass $\mathrm{C}_{\text {, }}$ its content found in the two layers of the transect is in the range observed in forest and grassland soils but exceeds that of arable soils (Wolters \& Joergensen, 1991; Kaiser et al., 1992). Cadée \& Hegemann (1977) found between 0.5 and $2.2 \mu \mathrm{g} \mathrm{ATP} \mathrm{ml}^{-1}$ sediment in intertidal flats. The conversion factor from $\mu \mathrm{g}$ ATP to $\mu \mathrm{g}$ biomass C varies between 140 for arable soils (Jenkinson, 1988) and 500 for subsurface aquifer sediments (Balkwill et al., 1988). Biomass estimates from the ATP data of Cadée \& Hegeman (1977) come close to those found by the fumigationextraction in this investigation. Assuming a bulk density of $1.25 \mathrm{~g} \mathrm{~cm}^{-3}$, the amount of microbial biomass would be $34 \mathrm{~g} \mathrm{C} \mathrm{m}^{-2}$ at $0-4 \mathrm{~cm}$ depth. In September in the Bay of Fundy (Canada), Schwinghamer (1983) found a maximum level of $19 \mathrm{~g} \mathrm{C} \mathrm{m}^{-2}(0-10 \mathrm{~cm}$ depth) originated from bacteria and algae using a direct count method. Findlay et al. (1989) found by direct counts a 3 to 4 times smaller microbial biomass than by phospholipid analysis. The phospholipid content of $1 \mathrm{~g}$ bacterial biomass varies between $50 \mu \mathrm{mol}$ (Findlay et al., 1989) and $250 \mu \mathrm{mol}$ (Moriarty et al., 1985). The factor of the fumigation-extraction method to convert $\mathrm{CHCl}_{3}$-labile $\mathrm{C}$ to microbial biomass $\mathrm{C}$ is less variable (Kaiser et al., 1992), but also not completely satisfactory because it was calibrated mainly for agricultural soils and not for oxic and anoxic sediments (Jenkinson, 1988; Wu et al., 1990). The difference in the community structures of the microbial population could not only affect the conversion of $\mathrm{CHCl}_{3}$-labile $\mathrm{C}$ into biomass $\mathrm{C}$ but also the interpretation of the data. In terrestric soils, a negligible difference in biomass exists between the heterotrophic microflora and the total microbial biomass, which is the sum of bacteria, fungi, algae and protozoa. In tidal flat sediments, the percentage of the autotrophic microflora, and presumably that of the microfauna, is comparatively higher. However, the amount of microfaunal organisms is still too small to make a considerable contribution to the microbial biomass estimates (Reise, 1985). Nevertheless, this problem should be considered when investigating the interaction of microflora and animals.

It is also possible that some non-biomass $\mathrm{C}$ is attacked and made extractable by $\mathrm{CHCl}_{3}$-fumigation. However, this error is assumed to be relatively small (Jenkinson, 1966). In contrast to $\mathrm{CHCl}_{3}$-labile $\mathrm{C}$, total organic $\mathrm{C}$ is closely correlated with physical factors, indicating a relatively good separation of biomass from non-biomass $\mathrm{C}_{\text {, especially }}$ considering the high ratio $\mathrm{CHCl}_{3}$-labile $\mathrm{C}$ to total organic $\mathrm{C}$. A more correct conversion factor could be obtained only if better methods for direct calibration of the fumigationextraction method are developed using in situ ${ }^{14} \mathrm{C}$-labelling of the sediment microbial biomass.

In contrast to the microbial biomass, the content of total organic $\mathrm{C}$ found in our sandy flat transect is very low compared to the yearly $\mathrm{C}$-input by algae and phytoplankton. Consequently, a microbial biomass $C$ to total organic $C$ ratio representing $40 \%$ is more than ten times larger in the oxic $0-2 \mathrm{~cm}$ layer than that found in terrestrial soils (Kaiser et al., 1992). Even in the anoxic $2-4 \mathrm{~cm}$ layer, the biomass $\mathrm{C}$ to total organic $\mathrm{C}$ ratio represents close to $30 \%$, pointing to the enormous productivity of the anaerobic microbial community of heterotrophic and autotrophic organisms. According to Insam et al. (1989), the ratio of microbial biomass $C$ to total organic $C$ is positively related to $C$ availability to microorganisms. However, the high content of microbial biomass is less astonishing in comparison with terrestrial soils than the very low level of accumulated 
non-biomass organic $C$ which consists almost completely of dead microbial residues. This low level of accumulated necromass may be caused by the following reasons:

(1) The C-input is easily decomposable. In contrast to all terrestrial soils and to tidal sediments with seagrass beds, no C-input originates from macrophytes. Phytoplankton and microalgae are the main producers of the C-input into our sediment transect. Their organic matter consists of proteins and other easily decomposable components as indicated by the very low $\mathrm{C}: \mathrm{N}$ ratios of total organic matter. An average sediment $\mathrm{C}: \mathrm{N}$ ratio of 6.6 was found by Schwinghamer (1983). These ratios are similar to those estimated for microorganisms in agricultural soils (Anderson \& Domsch, 1980).

(2) The faunal biomass, especially that of grazing organisms is large. The average annual biomass of the macrofauna alone amounts to about $15 \mathrm{~g} \mathrm{C} \mathrm{m}^{-2}$ (Reise, 1985), which is comparable to the total soil fauna in a calcareous beech forest (Schaefer \& Schauermann, 1990).

(3) The oxic and anoxic layer are closely connected in tidal sediments. The interface between the two layers moves up and down according to temperature, wave action, organic input, tidal percolation of interstitial water, and diurnal variation of oxygenic photosynthesis. The low energy yield of anoxic conditions leads to an enormous turnover of organic matter and rapid breakdown of polymers by fermentation. The products of these processes can be rapidly decomposed under oxic conditions. The continuous shift between oxic and anoxic conditions may lead to a nearly complete decomposition of organic material, thus hindering the accumulation of humic material.

(4) Suspended or dissolved organic matter is washed away by the tidal exchange of water masses. Easily decomposable material is often highly soluble, as are the fermentation products of anoxic processes. A relatively high percentage of material could be extracted by $0.5 \mathrm{M} \mathrm{K}_{2} \mathrm{SO}_{4}$. This might be an additional reason for the low accumulation of humic (non-biomass) material.

Extremely high ratios of microbial biomass $\mathrm{C}$ to total $\mathrm{C}$ and a large macrofaunal population indicate short turnover times and a more labile community than that of terrestrial soils. The amount of total organic carbon at the Canadian Bay of Fundy showed some marked fluctuations between sampling dates which could, however, also be a result of considerable spatial heterogeneity (Schwinghamer, 1983). The biomass level of algae showed the largest variations, ranging from $0.1 \mathrm{~g} \mathrm{C} \mathrm{m}^{-2}$ in winter and $12.6 \mathrm{~g} \mathrm{C} \mathrm{m}^{-2}$ in late summer (Schwinghamer, 1983). A relatively similar range between maximum and minimum content of algae was observed by Asmus (1982), who investigated an area close to our sandy flat. Also the benthic fauna shows very pronounced seasonal and interannual changes in abundance and composition of population structure - a species-specific annual maximum usually occurring between spring and winter (Reise, 1985). The fluctuations of the microbial biomass studied here may also depend considerably on the variations in environmental conditions such as $\mathrm{C}$-input, temperature, light and faunal abundance. The fumigation-extraction method may be a useful tool for monitoring such spatial and temporal variations caused by changes in climatic, faunal and physical habitat.

\section{LITERATURE CITED}

Alongi, D., 1988. Bacterial productivity and microbial biomass in tropical mangrove sediments. Microb. Ecol. 15, 59-79. 
Anderson, J. P. E. \& Domsch, K. H., 1980. Quantities of plant nutrients in the microbial biomass of selected soils. - Soil Sci. 130, 211-216.

Anderson, J. G. \& Meadows, P. S., 1978. Microenvironments in marine sediments. - Proc. R. Soc. Edinb. $76 \mathrm{~B}, 1-16$.

Asmus, R., 1982. Field measurements on seasonal variation of the activity of primary producers on a sandy tidal flat in the northern Wadden Sea. - Neth. J. Sea Res. 16, 389-402.

Asmus, H. \& Asmus, R., 1985. The importance of the grazing food chain for energy flow and production in three intertidal sand bottom communities of the Northern Wadden Sea. - Helgoländer Meeresunters. 39, 273-301.

Balkwill, D. L., Leach, F. R., Wilson, J. T., McNabb, J. F. \& White, D. C., 1988. Equivalence of microbial biomass measures based on membrane lipid and cell wall components, adenosine triphosphate, and direct counts in subsurface aquifer sediments. - Microb. Ecol. 16, 73-84.

Cadée, G. C. \& Hegeman, J., 1977. Distribution of primary production of the benthic microflora and accumulation of organic matter on a tidal flat area, Balgzand, Dutch Wadden Sea. - Neth. J. Sea Res. 11, 24-41.

Findlay, R. H., King, G. M. \& Watling, L., 1989. Efficacy of phospholipid analysis in determining microbial biomass in sediments. - Appl. environ. Microbiol. 55, 2888-2893.

Insam, H., Parkinson, D. \& Domsch, K. H., 1989. Influence of macroclimate on soil microbial biomass. - Soil Biol. Biochem. 21, 211-221.

Inubushi, K., Brookes, P. C. \& Jenkinson, D. S., 1991. Soil microbial biomass C, $\mathrm{N}$ and ninhydrin-N in aerobic and anaerobic soils measured by the fumigation-extraction method. - Soil Biol. Biochem. $24,737-741$.

Jenkinson, D. S., 1966. Studies on the decomposition of plant material in soil. II: Partial sterilization of soil and the soil biomass. - J. Soil Sci. 17, 280-302.

Jenkinson, D. S., 1988. The determination of microbial biomass carbon and nitrogen in soil. In: Advances in nitrogen cycling in agricultural ecosystems. Ed. by J. R. Wilson. CAB International, Wallingford, 368-386.

Jenkinson, D. S. \& Ladd, J. N., 1981. Microbial biomass in soil: measurement and turnover. - Soil Biochem. 5, 415-471.

Jenkinson, D. S., Harkness, D. D., Vance, E. D., Adams, D. E. \& Harrison, A. F., 1992. Calculating net primary production and annual input of organic matter to soil from the amount and radiocarbon content of soil organic matter, - Soil Biol. Biochem. 24, 295-308.

Joergensen, R. G. \& Meyer, B., 1990. Nutrient changes in decomposing beech leaf litter assessed using a solution flux approach. - J. Soil Sci. 41, 279-293.

Kaiser, E.-A., Mueller, T., Joergensen, R. G., Insam, H. \& Heinemeyer, O., 1992. Evaluation of methods to estimate the soil microbial biomass and the relationship with soil texture and organic matter. - Soil Biol. Biochem. 24,675-683.

Moriarty, D. J. W., Boon, P., Hansen, H., Hunt, W. G., Pointer, I. R., Pollard, P. C., Skrying, G. W. \& White, D. C., 1985. Microbial biomass and productivity in seagrass beds. - Geomicrobiol. J. 4, 21-51.

Mueller, T., Joergensen, R. G. \& Meyer, B., 1992. Estimation of soil microbial biomass C in the presence of fresh roots by fumigation-extraction. - Soil Biol. Biochem. 24, 179-181.

Reise, K., 1985. Tidal flat ecology. Springer, Berlin, $191 \mathrm{pp}$.

Schaefer, M. \& Schauermann, J., 1990. The soil fauna of beech forests: comparison between mull and a moder soil. - Pedobiologia 34, 299-314.

Schlichting, E. \& Blume, H, P., 1966. Bodenkundliches Praktikum. Parey, Hamburg, 212 pp.

Schwinghamer, P., 1983. Generating ecological hypotheses from biomass spectra using causal analysis: a benthic example. - Mar. Ecol. Prog. Ser. 13, 151-166.

Vance, E. D., Brookes, P. C. \& Jenkinson, D. S., 1987. An extraction method for measuring soil microbial C. - Soil Biol. Biochem. 19, 703-708.

Widmer, P., Brookes, P. C. \& Parry, L. C., 1989. Microbial biomass nitrogen measurements in soils containing large amounts of inorganic nitrogen. - Soil Biol. Biochem. 21, 865-867.

Wolters, V. \& Joergensen, R. G., 1991. Microbial carbon turnover in beech forest soils at different stages of acidification. - Soil Biol. Biochem. 23, 897-902.

Wu, J., Joergensen, R. G., Pommerening, B., Chaussod, R. \& Brookes, P. C., 1990. Measurement of soil microbial biomass C - an automated procedure. - Soil Biol. Biochem. 22, 1167-1169. 